\title{
Monitoring of Pollutant Levels in Stagnant and Flowing Water Bodies in and around Ahmedabad, India
}

\section{Hemil H Patel}

\begin{abstract}
There are various water bodies in and around Ahmedabad, India which serve as source of water for irrigation and other recreational purposes. The stagnant water bodies available are lakes such as Kankaria lake and Vastrapur lake whereas flowing water can be seen in form of Kharicut canal, or Sabarmati river which flow across the city. With increasing anthropogenic activities, pollutants levels have increased in these water bodies. Nitrogen and phosphorus are known to be the primary causes of eutrophication (i.e., nutrient enrichment due to human activities) in those surface waters. Around 110 years ago Kharicut canal was built for providing potable water as well as for irrigation on peripheries of Ahmedabad district. Uncontrolled release of wastewater from various sources including municipal treatment plants, industrial treatment plants and common effluent treatment plants led to pollution of Kharicut canal and further adversely affected the farms and their crops. Apart from the orders given by High Court in 2016 for cleaning of canal and recent reports of the leading newspaper, Times of India also represented still worst conditions of canal. So providing adequate sanitation and clean water to villages and lakes through the Kharicut canal is a burning issue and economic challenge for the Gujarat Government. The water from various water bodies were collected and analysed for BoD, COD, TDS, Phosphate, pH, salinity etc. The water samples revealed alkaline water in all the locations. Most of the nutrients were in the range however COD in Kharicut Canal was alarming.
\end{abstract}

Keywords: Water purity, BOD, COD, Pollution.

\section{INTRODUCTION}

There are various water bodies in and around Ahmedabad, India which serve as source of water for irrigation and other recreational. Approximately $25 \%$ of all water contamination are due to nutrient-related causes (e.g., nutrient inputs, oxygen depletion, algal growth, ammonia, harmful algal blooms affecting biological integrity and turbidity) [1]. There have been many chemical and biological approaches for removal of nutrients from the water. Neutralization and application of flocculants and coagulants like, alum and $\mathrm{FeSO}_{4}$ have been employed as traditional processes in effluent treatment plants for phosphorus removal [2].

Manuscript received on October 11, 2021.

Revised Manuscript received on October 20, 2021.

Manuscript published on October 30, 2021.

* Correspondence Author

Hemil H. Patel*, Student, Sattva Vikas School, Ahmedabad (G.J), India.

(C) The Authors. Published by Blue Eyes Intelligence Engineering and Sciences Publication (BEIESP). This is an open access article under the CC BY-NC-ND license (http://creativecommons.org/licenses/by-nc-nd/4.0/)
During wastewater treatment, even after secondary biological treatment by activated sludge system where degradable organics are removed, much amount of nonbiodegradable organic and inorganic pollutants remain in effluents contributing to high chemical oxygen demand (COD) levels. These high COD and BOD values in treated effluent usually exceed the maximum permissible limit. Hence this water cannot be used even for irrigation purpose. Usually according to Gujarat Pollution Control Board (GPCB) guidelines, the permissible limit of COD and BOD in industrial wastewater is $250 \mathrm{mg} / \mathrm{ml}$ and $30 \mathrm{mg} / \mathrm{ml}$ respectively [3].

The various studies on river contamination in India are reported. Gopal et al., 2021 collected and analysed water samples from 35 locations in the Arkavathi river, its tributaries and lakes spread across the Bengaluru metropolitan area in Southern India during monsoon. They reported that Ibuprofen was present in high concentrations $(1834 \mathrm{ng} / \mathrm{L})$ followed by triclosan (1761 ng/L) and diclofenac (1130 ng/L) in the river [4]. Williams et al., 2019 carried out longitudinal survey of a small Indian city's river receiving untreated wastewater wherein emerging contaminants were detected and concluded that minimal attenuation of contaminants beyond city limits indicated the river was largely composed of untreated wastewater. They recommend that a wastewater treatment facility would substantially reduce most contaminant loads within the receiving environment [5]. Bhanu and Vellanki, 2021 employed the studies on detection of 16 emerging contaminants (ECs), including pharmaceuticals, personal care products and hormones in river Yamuna [6] Nandeshwar et al., 2016 conduced iron contamination study for the Nag River (India). They treated water with various adsorbents like orange peels, coconut shells, sawdust etc. out of which the most promising green adsorbents were found to be orange peels and the best activating agent was $\mathrm{HCl}$ [7]. Birol and Das, 2010 suggested improvements in the capacity and technology of a sewage treatment plant in Chandernagore municipality, located on the banks of the River Ganga in India [8]. The similar studies of river and local water body contamination are reported for the various parts of the world [9]. Kassa, 2021 evaluated the hazardous effects of untreated municipal wastewater discharge from the city of Bahir Dar to the head of the Blue Nile River. This was done by collecting wastewater samples from the upper, middle and lower sites of the stream and characterizing its physicochemical qualities. In all cases, tap water was taken as a control and the wastewater qualities were significantly varied among the studied sites.

\section{Published By:}

Blue Eyes Intelligence Engineering

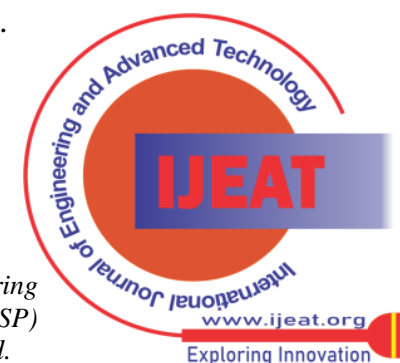


The highest values of EC, TDS, COD, etc. were found at the middle site [10]. Nieto-Juárez et al., 2021 studied removal of the pharmaceutical substances in municipal wastewater treatment plants (MWWTPs) from Peru and the impact of these compounds in surface waters receiving treated wastewater. Acetaminophen was the drug found at the highest concentration, and it was present in all the treated wastewater samples reaching average values above $100 \mu \mathrm{g} / \mathrm{L}$ in the department of Puno [11].

In this present study, the aim was to study the pollutant levels in terms of nutrient concentrations and COD and BOD values in various stagnant and flowing water bodies in and around Ahmedabad.

\section{MATERIALS AND METHODS}

\section{A. Physicochemical characterization}

All the samples collected were investigated for $\mathrm{pH}$, temperature, salinity, electrical conductivity, TDS etc. using automated multimeter. Samples were centrifuged at 7500 rpm at room temperature. Biochemical oxygen demand (BOD) and chemical oxygen demand (COD) were determined by standard methods [12] (APHA, 2005) for the selected samples. Total phosphate level was also determined for nutrient estimation.

\section{B. Biochemical oxygen demand (BOD) determination}

Bacteria utilize dissolved oxygen (DO) present in wastewater for oxidation of organic matters present. Biochemical oxygen demand (BOD) is the amount of oxygen consumed by bacteria while they decompose organic matter under aerobic conditions at $25{ }^{\circ} \mathrm{C}$. The amount of reduced DO is directly proportional to the amount of organic matter present in the sample. Higher the BOD, higher is the concentration of organic matter present in the water. BOD is used often in wastewater-treatment plants as an index of the degree of organic pollution in water. BOD was estimated by measuring dissolved oxygen. Two parallel sets of BOD bottles were filled with sample water. One was used for determination of $\mathrm{DO}$ value $\left(\mathrm{D}_{0}\right)$ and another was incubated at $20{ }^{\circ} \mathrm{C}$ for 3 days, following which DO was determined $\left(D_{3}\right)$ from this water.

\section{Chemicals and Reagents:}

a. $0.025 \mathrm{~N} \mathrm{Na}_{2} \mathrm{~S}_{2} \mathrm{O}_{3}$ : (0.1 N Stock): Dissolve $24.82 \mathrm{~g}$ $\mathrm{Na}_{2} \mathrm{~S}_{2} \mathrm{O}_{3}$ in distilled water and make the final volume to 1 litre. Prepare in volumetric flask: $250 \mathrm{ml}$ of $0.1 \mathrm{~N}$ $\mathrm{Na}_{2} \mathrm{~S}_{2} \mathrm{O}_{3}$ and add $750 \mathrm{ml}$ distilled water $(\mathrm{d} / \mathrm{w})$.

b. $\mathrm{MnSO}_{4}$ : Dissolve $480 \mathrm{~g}$ of $\mathrm{MnSO}_{4} \cdot 4 \mathrm{H}_{2} \mathrm{O}$ in distilled water and make the final volume to 1 litre.

c. Concentrated $\mathrm{H}_{2} \mathrm{SO}_{4}$

d. Alkaline iodide azide: Dissolve $500 \mathrm{~g}$ of $\mathrm{NaOH}, 150 \mathrm{~g}$ of KI in little amount of distilled water, add $10 \mathrm{~g}$ of $\mathrm{NaNO}_{3}$ in $40 \mathrm{ml} \mathrm{d} / \mathrm{w}$. Mix both the reagent and make the final volume to 1 litre.

e. $0.5 \%$ Starch: Dissolve $0.5 \mathrm{~g}$ of starch in $100 \mathrm{ml} \mathrm{d} / \mathrm{w}$ by heating.

Procedure:

1. Sample was filled till the top in BOD bottle. Two parallel sets of BOD bottles were filled with each sample water. As the strength of the waste (organic load) was not known in various water samples, various dilutions were made arbitrarily. So, 1:2, 1:4, 1:6, 1:8, $1: 10$, and $1: 20$ dilutions were made from the collected water samples. Undiluted water sample was also taken. Hence total 14 bottles were taken for each water sample. Aerated d/w was used for preparing dilutions. One bottle from each dilution was incubated at $20^{\circ} \mathrm{C}$ for 3 days. The other bottle from each dilution was immediately used for determination of $D_{0}$ values of DO.

2. For estimation of $\mathrm{DO}, 2 \mathrm{ml}$ of $\mathrm{MnSO}_{4}$ and $2 \mathrm{ml}$ of alkaline iodide azide reagents were added in the bottle.

3. One ml concentrated $\mathrm{H}_{2} \mathrm{SO}_{4}$ was added. The excess water was allowed to spill.

4. One hundred $\mathrm{ml}$ of sample was taken from bottle and one ml starch was added. Color changed to deep blue.

5. The mixture was titrated with $0.025 \mathrm{~N} \mathrm{Na}_{2} \mathrm{~S}_{2} \mathrm{O}_{3}$ till the color changed to colorless.

6. The DO was calculated using the following formula:

7. Dissolved $\mathrm{O}_{2}$ in $\mathrm{mg} / \mathrm{l}=$ Burette reading $\mathrm{x} \mathrm{N}$ of $\mathrm{Na}_{2} \mathrm{~S}_{2} \mathrm{O}_{3}$ x $8000 / \mathrm{ml}$ of sample

8. After 3 days, DO readings were taken from the second bottle and BOD was calculated using the following formula.

\section{C. $B O D=(D 0-D 3) \times$ Dilution Factor}

where,

$\mathrm{D}_{0}=$ dissolve oxygen at day 0

$\mathrm{D}_{3}=$ dissolve oxygen at day 3

The BOD value of a sample was calculated by taking average of all the possible BOD values obtained from different dilutions.

\section{Chemical oxygen demand (COD)}

COD is the indicative measurement of amount of the oxygen that can be consumed by organisms in wastewater for oxidation of the organics present. Specifically, it measures the equivalent amount of oxygen required to chemically oxidize organic compounds in water. The COD test is often used to monitor water treatment plant efficiency and use to keep a check on residual organic material in wastewater. This test is based on the fact that a strong oxidizing agent, under acidic conditions, can fully oxidize almost any organic compound to carbon dioxide and water. It is an important and rapidly measured variable for characterizing water bodies, sewage, industrial wastes, and treatment plant effluents. Higher COD levels mean that a greater amount of oxidizable organic material is present in the sample, and indicate organic pollution of the water body. Higher amount of degradable or oxidizable organics present will lead to depletion of DO of that water body due to microbial and algal activity which may prove deleterious to aquatic life forms.

\section{Chemicals and Reagents:}

a. $\mathrm{K}_{2} \mathrm{Cr}_{2} \mathrm{O}_{7}$ : Dissolve $12.258 \mathrm{~g} \mathrm{~K}_{2} \mathrm{Cr}_{2} \mathrm{O}_{7}$ in $1000 \mathrm{ml}$ distilled water.

Published By:

Blue Eyes Intelligence Engineering

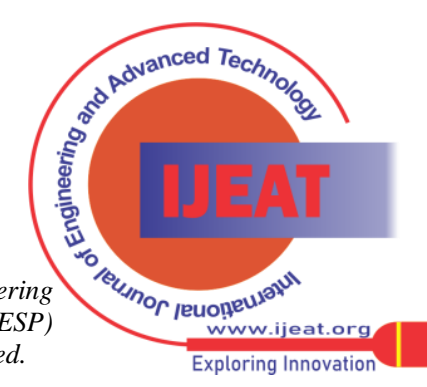


b. $\quad$ FAS (Ferrous Ammonium Sulfate): Dissolve $39.29 \mathrm{~g}$ FAS into some amount of distilled water then add 20 ml concentrated $\mathrm{H}_{2} \mathrm{SO}_{4}$ and make up the final volume up to $1000 \mathrm{ml}$ with distilled water.

c. $\mathrm{HgSO}_{4}$ Crystals

d. Ferroin indicator: Dissolve $695 \mathrm{mg}$ Ferrous sulfate and 1.458 g 1, 10- Phenanthroline monohydrate in $100 \mathrm{ml}$

e. $\mathrm{H}_{2} \mathrm{SO}_{4}+\mathrm{AgSO}_{4}$ reagent: Dissolve $10.1 \mathrm{~g} \mathrm{AgSO}_{4}$ in $1000 \mathrm{ml} \mathrm{H}_{2} \mathrm{SO}_{4}$.

Procedure:

1. Total of $25 \mathrm{ml}$ sample was taken in a reflux flask for COD estimation with the ratio of $24 \mathrm{ml}$ of double distilled water $+1 \mathrm{ml}$ water sample.

2. Following reagents were added into flask sequentially

$0.5 \mathrm{~g} \mathrm{HgSO}_{4}$ (1 pinch),

$2.5 \mathrm{ml} \mathrm{H}_{2} \mathrm{SO}_{4}+\mathrm{AgSO}_{4}$ reagent,

$12.5 \mathrm{ml} \mathrm{K}_{2} \mathrm{Cr}_{2} \mathrm{O}_{7}$ solution, and

$35 \mathrm{ml} \mathrm{H}_{2} \mathrm{SO}_{4}+\mathrm{AgSO}_{4}$ reagent

3. After cooling the sample, 5-6 porcelain beads were added and flask was placed on heater for $2 \mathrm{~h}$ at $70^{\circ} \mathrm{C}$ temperature.

4. Flasks were joined with condenser. The tap water was allowed to get filled with water.

5. After 2 h, condenser was disconnected and sample was allowed to cool down.

6. Total volume was made up to $100 \mathrm{ml}$ by using double distilled water in $250 \mathrm{ml}$ flask.

7. Ferroin indicator of 3-5 drops was added and sample was titrated with $(0.1 \mathrm{~N})$ FAS.

8. The colour change from pale yellow to green to blue to red was recorded.

\section{E. Phosphate estimation (SnCl2 method)}

Chemicals and Reagents

a. Phenolphthalein Indicator

$500 \mathrm{mg}$ Phenolphthalein was dissolved in $50 \mathrm{ml}$ ethyl/ isopropyl alcohol and then $50 \mathrm{ml}$ distilled water was added. $0.02 \mathrm{~N} \mathrm{NaOH}$ solution was added drop wise to this solution until faint pink colour appears.

b. Sulfuric acid - Nitric acid reagent

$75 \mathrm{ml}$ concentrated $\mathrm{H}_{2} \mathrm{SO}_{4}$ is added to about $150 \mathrm{ml}$ of distilled water. The solution was kept for sometimes to cool down and $1 \mathrm{ml}$ concentrated $\mathrm{HNO}_{3}$ was added followed by diluting it to $250 \mathrm{ml}$ distilled water.

c. Ammonium Molybdate reagent

Part 1: Dissolve 25 g of Ammonium Molybdate in 200 $\mathrm{ml}$ distilled water.

Part 2: Add $280 \mathrm{ml}$ concentrated $\mathrm{H}_{2} \mathrm{SO}_{4}$ to $400 \mathrm{ml}$ distilled water. Add molybdate solution to part 2 and make up to total of $1000 \mathrm{ml}$.

d. $\mathrm{SnCl}_{2}$ solution

$2.5 \mathrm{~g}$ of fresh $\mathrm{SnCl}_{2}$ was added in $100 \mathrm{ml}$ glycerol and heated in water bath to dissolve.

e. $\mathrm{KH}_{2} \mathrm{PO}_{4}$ stock solution

$439 \mathrm{mg}$ of $\mathrm{KH}_{2} \mathrm{PO}_{4}$ was dissolved in $1000 \mathrm{ml}$ distilled water in which further two drops of toluene was added as preservative.

f. $\mathrm{KH}_{2} \mathrm{PO}_{4}$ working solution distilled water.

Freshly dilute the stock solution 1:100 times to give final phosphorus concentration of $1 \mathrm{ml}=1 \mu \mathrm{g} \mathrm{P}=3.06$ $\mu \mathrm{g} \mathrm{PO}_{4}$.

\section{F. Procedure}

1. Suitable aliquot of the centrifuged sample (containing not more than $20 \mu \mathrm{g}$ of phosphate) was taken and one drop of phenolphthalein indicator was added. If pink colour appeared, two to three drops of sulfuric acid nitric acid solution was added to neutralize the solution.

2. Four micro liter of Ammonium molybdate reagent and $0.5 \mathrm{ml}$ of stannous chloride solution were added to the sample. The contents were mixed well after each addition.

3. After 10 min but before 15 minutes absorption was read at $690 \mathrm{~nm}$.

4. Calibration curve was prepared using Potassium dihydrogen phosphate as standard.

\section{RESULTS}

Though the Biological Nutrient Removal (BNR) has been practiced in wastewater treatment plants since long, lot of nutrients are still released in the treated water.

All types of nutrient present in the water originate from a variety of sources, and amongst them nitrogen $(\mathrm{N})$ and phosphorus (P) have been regarded as the most important due to their impact on the aquatic life.

Being the limiting nutrients for algal growth in fresh water bodies they directly influence the acceptability of water in recreational bodies like lakes. Figure 1 depicts the calibration curve for phosphorous estimation by $\mathrm{SnCl}_{2}$ method.

Concentration of $\mathrm{PO}_{4}$ in samples collected from various time intervals was determined using the equation. The biochemical characteristics of the water samples collected from different lakes are shown in Table 1. The DO levels in these water samples ranged between 1.2 to $1.8 \mathrm{mg} / \mathrm{L}$.

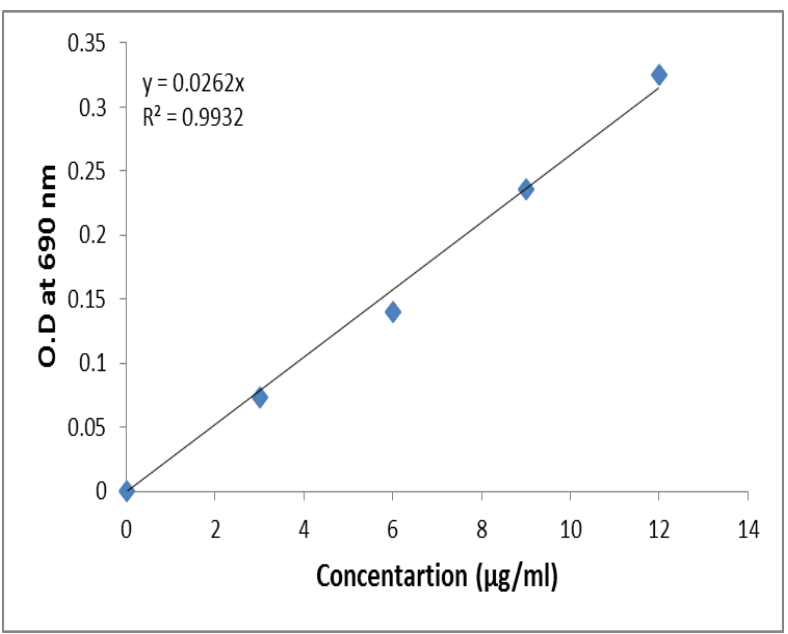

Figure 1: Standard curve for phosphorous estimation by $\mathrm{SnCl}_{2}$ method

Published By: Blue Eyes Intelligence Engineering

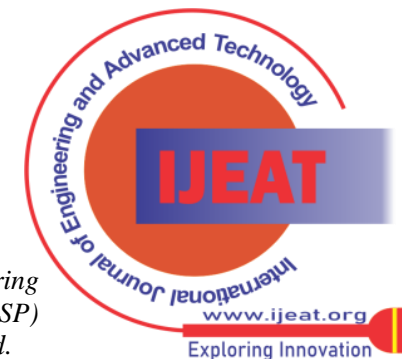


Table 1: Comparative data of physic-chemical analysis of lake water samples

\begin{tabular}{|c|c|c|c|c|c|}
\hline Lake & pH & $\begin{array}{c}\text { Conductivity } \\
(\boldsymbol{\mu s})\end{array}$ & salinity & TDS & $\begin{array}{c}\text { Phosphate } \\
(\mathbf{p p m})\end{array}$ \\
\hline Kankaria & 9.0 & 1961 & $\begin{array}{c}1.09 \\
\mathrm{ppt}\end{array}$ & $\begin{array}{c}1.38 \\
\mathrm{ppt}\end{array}$ & 2.850 \\
\hline Chiloda & 9.4 & 468 & $\begin{array}{c}250 \\
\mathrm{ppm}\end{array}$ & $\begin{array}{c}333 \\
\mathrm{ppm}\end{array}$ & 2.693 \\
\hline Nikol & 9.5 & 1519 & $\begin{array}{c}832 \\
\mathrm{ppm}\end{array}$ & $\begin{array}{c}1.07 \\
\mathrm{ppt}\end{array}$ & 2.857 \\
\hline Manipur & 9.6 & 420 & $\begin{array}{c}223 \\
\mathrm{ppm}\end{array}$ & $\begin{array}{c}292 \\
\mathrm{ppm}\end{array}$ & $\mathrm{ND}$ \\
\hline
\end{tabular}

Note: 'ND'-Not determined

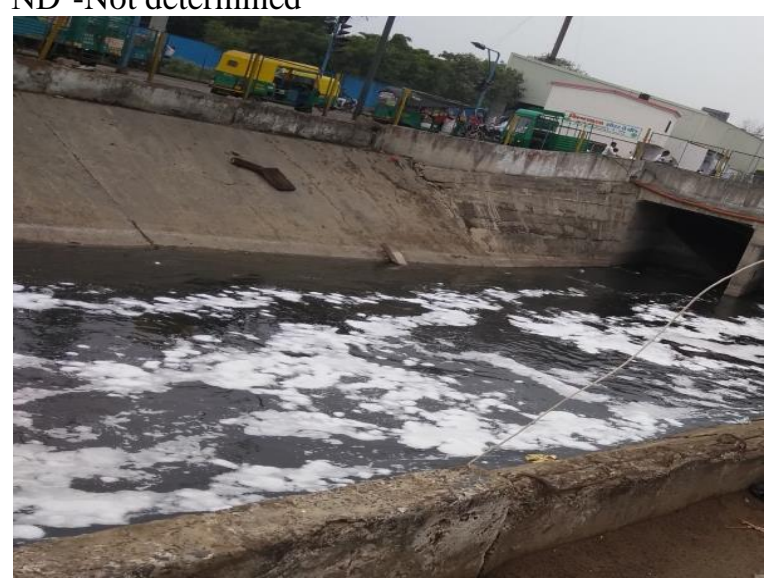

(a)

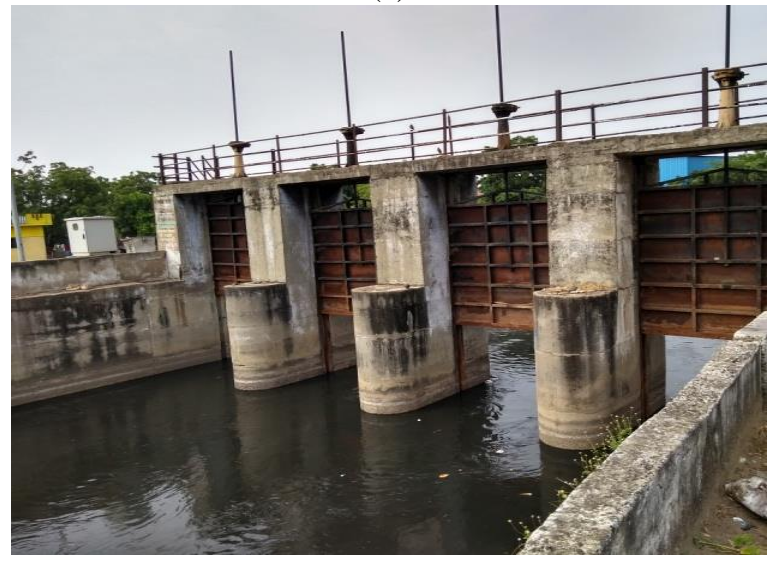

(c)
All the samples were found to have different properties. All the samples showed alkaline $\mathrm{pH}(\mathrm{pH} \geq 9.0)$. Electrical conductivity, salinity and TDS were high in Kankaria lake water sample as compared to the water samples collected from other lakes. Water sample collected from Nikol lake also had high TDS demonstrating higher pollutant level in the water body. Amount of phosphate concentration was almost same for all the lake water samples. Four water samples were collected from different sites of Kharicut canal are shown in Figure 2. Their physic-chemical parameters are shown in Table 2.

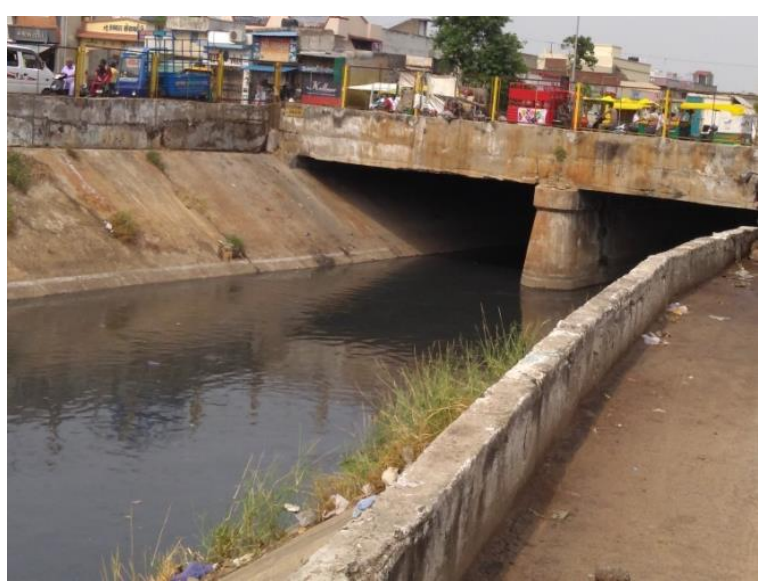

(b)

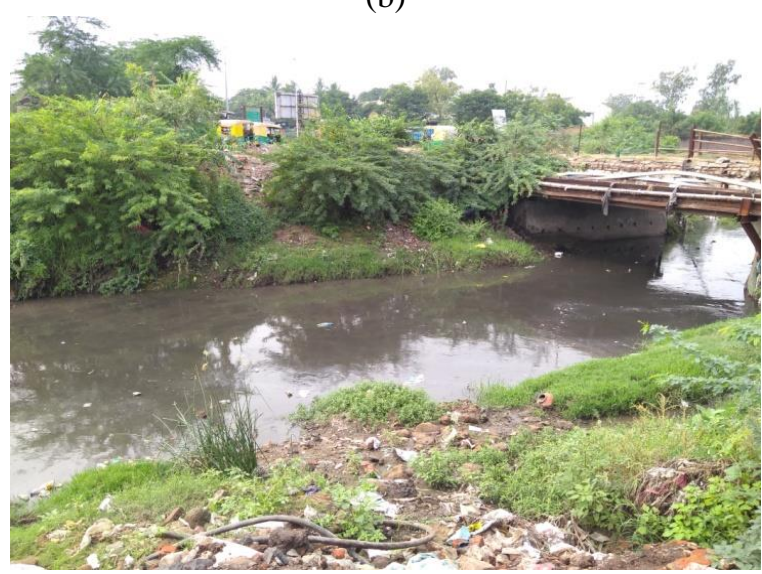

(d)

Figure 2: water sample collection site from Kharicut canal. (a) Site 1: Near Jay Chemical Industries and OEPL, (b) Site 2: Near Odhav, (c) Site 3: Near RTO, (d) Site 4: Near CETP Vatva GIDC.

and conductivity along with COD. The reason of higher TDS and COD of sample 4 might be due to the collection site which is near GIDC, Vatva, and a most well-known industrial zone in Ahmedabad.

\section{CONCLUSION}

Out of total 39 small, medium sized and large lakes in the Ahmedabd city of India, samples from 4 lakes were collected on the basis of the diversity of the area and exposure to human activities. All the water samples were found to be alkaline in nature having more than $9 \mathrm{pH}$.

From the above results, it can be concluded that samples S-2 and S-4 contained higher organic load as compared to samples S-1 and S-3 as they have higher COD and BOD values. Although presence of maximum pollutant can be predicted in Sample 4 (S-4) as it contained maximum TDS,

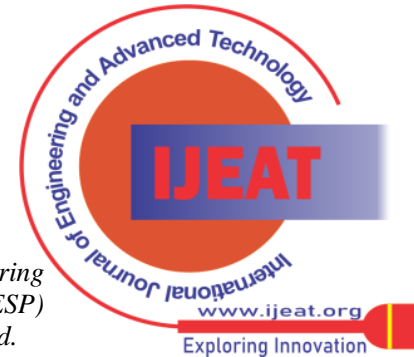


The dissolved oxygen level of all the lake water samples were ranging in between 1.2 to $1.8 \mathrm{mg} / \mathrm{l}$. Nitrogen and phosphorus are the primary causes of cultural eutrophication (i.e., nutrient enrichment due to human activities) in surface waters. Though the phosphate content was almost same for all water samples collected from lake and hence this nutrient was present in negligible concentration. Kharicut canal which was primarily built for irrigation purpose became polluted in the industrial zone and it is an alarming sign as the COD exceeds the permissible limit $(250 \mathrm{mg} / \mathrm{L})$ detected by Gujarat Pollution Control Board (GPCB). This indicates the requirement of proper treatment of wastewater to reduce COD levels before being released in the canal water.

\section{REFERENCES}

1. W.S. Davis, EPA's 2007 Report on the Environment: Approach for Selection and Documentation of Indicators for Reporting on the Condition of the Nation's Water Resources, American Water Resources Association 2006 Annual Water Resources Conference, Baltimore, Maryland November 6-9, 2006.

2. Maharashtra Pollution Control Board (MPCB) guidelines on hazardous waste generation, 2004

3. Gujarat Pollution Control Board (GPCB) guidelines on water and wastewater, https://gpcb.gujarat.gov.in/, 2010.

4. C.M. Gopal, K. Bhat, B.R. Ramaswamy, V. Kumar, R.K. Singhal, H. Basu, H.N. Udayashankar, S.G. Vasantharaju, Y. Praveenkumarreddy, Shailesh, Y. Lino, K. Balakrishna, Seasonal occurrence and risk assessment of pharmaceutical and personal care products in Bengaluru rivers and lakes, India, Journal of Environmental Chemical Engineering, 9 (2021), 105610.

5. M. Williams, R. Kookana, A. Mehta, S.K. Yadav, B.L. Tailor, B Maheshwari, Emerging contaminants in a river receiving untreated wastewater from an Indian urban centre, Science of The Total Environment, 647 (2019) 1256-1265.

6. P.B. Bhanu, P. Vellanki, Occurrence of emerging contaminants in highly anthropogenically influenced river Yamuna in India, Science of The Total Environment, 782 (2021) 146741.

7. S.N. Nandeshwar, A.S. Mahakalakar, R.R. Gupta, G.Z. Kyzas, Green activated carbons from different waste materials for the removal of iron from real wastewater samples of Nag River, India, Journal of Molecular Liquids, 216 (2016) 688-692.

8. E. Birol, S. Das, Estimating the value of improved wastewater treatment: The case of River Ganga, India, Journal of Environmental Management, 91 (2010) 2163-2171.

9. G. Mao, Y. Han, X. Liu, J. Crittenden, N. Huang, U.M. Ahmad, Technology status and trends of industrial wastewater treatment: A patent analysis, Chemosphere, 2021, 132483 (article in press).

10. B.A. Kassa, Cytotoxicity and Genotoxicity evaluation of municipal wastewater discharged into the head of Blue Nile River using the Allium Cepa test, Scientific African, 2021, 911 (article in press).

11. J.I. Nieto-Juárez, R.A. Torres-Palma, A.M. Botero-Coy, F. Hernández, Pharmaceuticals and environmental risk assessment in municipal wastewater treatment plants and rivers from Peru, Environment International, 155 (2021) 106674 (article in press).

12. A.D. Eaton, American Public Health Association; American Water Works Association; Water Environment Federation. Standard Methods for the Examination of Water and Wastewater. APHA (2005), 21 ${ }^{\text {st }}$ Edition, American Public Health Association/American Water Works Association/Water Environment Federation, Washington DC.

\section{AUTHOR PROFILE}

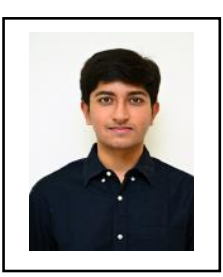

Hemil $\mathbf{H}$ Patel is a $12^{\text {th }}$ grade student of Sattva Vikas School in Ahmedabad, India. $\mathrm{He}$ is a passionate research student and this paper is one of his few research works heralding his entry into the research field. He is an energetic and effective leader of the School Science Club who carried out many innovative initiatives like conducting of webinars and organizing industry visits during the covid-induced lockdown, for benefit of his fellow students. Hemil plans to pursue his undergraduate studies in Engineering in USA and would like to take up research assignments in the field of Engineering.

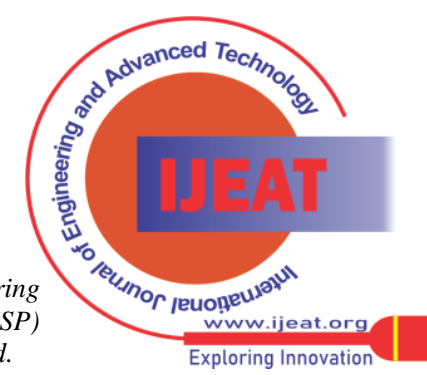

